\title{
The science teacher's opinions about using performance assessment in elementary science education
}

\author{
Omer Kutlu ${ }^{1}$, Ozen Yildirim ${ }^{2}$, Safiye Bilican Demir ${ }^{3,}$ * \\ ${ }^{1}$ Ankara University, Department of Educational Science, Ankara, Turkey \\ ${ }^{2}$ Nigde University, Department of Educational Science, Nigde, Turkey \\ ${ }^{3}$ Kocaeli University, Department of Educational Science, Kocaeli, Turkey \\ Email address: \\ kutlu@education.ankara.edu.tr (O. Kutlu), ozenyildirim@nigde.edu.tr (O. Yildirim), safiye.demir@kocaeli.edu.tr (S. B. Demir)
}

\section{To cite this article:}

Omer Kutlu, Ozen Yildirim, Safiye Bilican Demir. The Science Teacher's Opinions about Using Performance Assessment in Elementary Science Education. International Journal of Elementary Education. Vol. 3, No. 6, 2014, pp. 121-127. doi: 10.11648/j.ijeedu.20140306.12

\begin{abstract}
Since the implementers of curriculum in schools are the teachers, it is imperative that teachers' opinions are taken into account on new approaches and methods like performance assessment used in science education. Therefore, the views of teachers should be clearly found out. The aim of this research was to determine the views of elementary science teachers towards the use of performance assessment. The research was conducted with 148 science teachers. According to results, however the frequency of using performance assessment during the training is not very high enough, the percentage of teachers who use performance assessment once or twice in an educational year was higher than the percentage of teachers who just use one or not,. The primary reason for teachers to use performance assessment was "transferring learned science subjects in the classroom to its applications in real life," and "encouraging students to research and collect data." The most important difficulty they encounter while using performance assessment was "parents' help." They thought that parents assist their kids more than teachers expect. They sometimes do the whole assignment on behalf of students. Besides this finding, while evaluating students' assignments in performance assessment the teachers frequently prefer to use the decisions from their professional experiences and scoring rubrics.
\end{abstract}

Keywords: Elementary Science Education, Performance Assessment, Science Curriculum, Science Teachers' Views

\section{Introduction}

Every event happening around us is a matter of science and this renders science as an indispensable part of life. As the world becomes increasingly dependent on science and technology, our health, the future of this planet and the growth of economy depend on how wisely we understand and consume the scientific knowledge (American Association for the Advancement of Science [AAAS], 1993). Especially the developments in science generate important changes in human lives and serve mankind by simplifying life. This situation indicates the importance of increasing the number of science literates in a country. The NSES (NRC, 1996) defines scientific literacy as,

"the knowledge and understanding of scientific concepts and processes required for personal decision making, participation in civic and cultural affairs, and economic productivity." (p. 22).
A science literate is accustomed to the natural world and can use scientific process skills for individual and social life purposes (Martin, Sexton, Franklin, \& Gerlovich, 2001). Increasing the number of science literates will be directly correlated to the importance that countries give to science education. Science education enables students to learn by active participation to lectures, by doing and living, trying, observing and making research. Yager and Perker (1988) argued that individuals adapt to developing and changing technology more easily by science education, produce solutions to social problems by using science and develop expertise and education consciousness. Especially reaching the mentioned skills for children, who face comprehensive science education in primary education level, is provided with the objectives in science programs. The objectives of the science education for a student involve; making research by using scientific knowledge, discovering new conditions, designing and creating, and using knowledge in their daily lives (Kaptan, 1998). Therefore, producing scientifically literate citizens has been a core goal of science education 
reform initiatives. These definitions place new demands on what we teach in science classrooms, how we teach science, and how we assess students' learning in science

Although behaviorism was the dominant paradigm throughout the 20th century, cognitive and constructivist theories of learning emerged in the 1990s to shift how assessment is viewed and used (Shepard, 2000). The current reform movement in science education is based on a constructivist approach to teaching and learning. The constructivist approach emphasizes that knowledge cannot be transmitted through memorization but must be constructed by both the individual and by social processes (Driver, Asoko, Leach, Mortimer, \& Scott, 1994).

Countries attempt to develop their science education programs, improve the quality of teachers and educational institutions with tools and equipment (Ayas, Çepni, \& Akdeniz, 1993). Some important modifications have also been implemented in science education programs in Turkey since 2004. The first implementation was the changing of the course's name. The name of this course which was once called "Science" was changed to "Science and Technology". They wanted to emphasize the instructional program. The units in the new science program were organized on the basis that the content could be reached through scientific processes (observation, designing and carrying out experiments, research, setting hypothesis, etc.). Therefore, this instructional program aims to give importance to researching and investigation, train students who are curious about the natural world to understand the nature of science and technology, and to have the skills of critical and creative thinking (MEB [Ministry of National Education], 2005). Thus, the traditional assessment approaches are inadequate in assessing development of these features of the students.

Typical classrooms assessments such as tests and quizzes were criticized because they focused primarily on content and were geared toward assessing lower level-thinking (Wiggins, 1989). These assessments did not evaluate other highly valued student abilities, such as the capacity to pose questions or conduct scientific inquiry. By means of the assessment and measurement techniques used for many years, the knowledge of the student was measured within a limited time, the students did not have the opportunity to see their achievements and deficiencies and not enough information about the learning schemas they created was presented. This kind of approaches could measure the low level knowledge and skills but are inadequate in terms of assessing high order of thinking skills (Shepard, 2000).

When the skills are taken into consideration in the renewed curriculum, it is obvious that performance based assessment approaches (alternative assessment methods like performance portfolio assessment, projects, based on self- and peer assessment) are necessary. The use of alternative forms of assessment other than multiple-choice, fill-in, and matching approaches have paralleled the shift to a constructivist paradigm.

Performance assessment measures higher-level thinking, deep conceptual understanding, and habits of mind (Marzano,
Pickering \& McTighe 1993; Ryan, 2006). Performance assessment may consist of an authentic task that requires students to apply what they know in a real-world context. In this context, it is required that the students take more active roles in classes, be aware of the problems around them, provide different solutions for these problems and organize activities that help them to maintain their learning process efficiently. What is essential in effective teaching is structuring the information, and this can be well achieved by assigning performance tasks to the students (Marzano et al., 1993).

The purpose of the performance assessment is to make students use and develop cognitive, affective and psychomotor skills like critical thinking, problem solving, reading comprehension, using creativity, researching and presenting a product (Haladyna, 1997; Popham, 2005). With the performance assessment, the students are expected to accomplish more complex tasks which require higher order thinking rather than the tasks which require simple, clear and low level of thinking skills (Kutlu, Doğan, \& Karakaya, 2008). Performance assessment attempts to measure how well a student uses the basic information while accomplishing the complex tasks in real life situations and make the student produce new information beyond using given information. The main purpose in using performance assessment is to get more accurate information on how students use the basic knowledge and skills they learn at schools in real life and to contribute to the development of their high order of thinking processes configuring the information (Mehrens,1992; Reynolds, Livingston, \& Wilson, 2006; Weglage, Newmann, \& Secada, 1996).

An analysis of recent science education literature and national science education reform documents suggests that change in schools is a complex process that does not happen overnight and is subject to the influence of teacher's attributes (Berliner, 2006; Gess-Newsome, Southerland, Johnston, \& Woodbury, 2003). When performance assessments are embedded into instruction, they engage students in the learning process, promote the development of 21 st century skills, and, at the same time, provide teachers with important information to make instructional decisions. However, the effective implementation of performance assessment at the classroom level requires teacher collaboration, training, and time allotted in the curriculum. Science educators maintain that science education reform fails partly because the assessment methods that teachers use do not serve the purposes of science education reform. Although improvements are being made in content standards, traditional pedagogies and assessment methods still dominate science classrooms across the nation (Brickhouse, 2006). Teachers' conceptions of assessment along with knowledge are necessary to translate these conceptions into practice (Gess-Newsome et al., 2003).

The restructuring of the schools, renewal of the science instructional curriculum and reorganization of the expected objectives cannot improve the instruction and instructional quality on its own (Elmore, 1992). Since the implementers of 
the educational programs in schools are the teachers, it is imperative that teachers' opinions on modern approaches and methods used in science education be correctly understood. Moreover, when the literature is reviewed, it could be seen that there are few studies on the views of teachers on alternative assessment. Therefore, the views of teachers, who play an effective role in assessment and evaluation of students' achievement, about the use of performance tasks within the educational practices as a significant part of performance-based assessment processes should be clearly found out. Thus, the results and findings of such studies will not only assist to identify the problems regarding the current applications, but also pave the way to find solutions in order for these applications to achieve their objectives. What is more the results and findings of such research will prove valuable clues in terms of the development of teachers' knowledge and skills in the desired direction on this subject.

The purpose of this study is to determine the opinions of elementary science teachers on performance tasks used in science courses. The following questions were asked for this purpose.

Of the teachers,

- How often do they use performance assessment in an educational year?

- What are their primary purposes of using performance tasks?

- Which difficulties do they encounter while using performance tasks?

- Which methods do they use while evaluating the performance tasks?

\section{Method}

\subsection{Research Model}

The survey model was utilized. The survey study is as a research model that identifies and describes a situation that existed in the past or still exists. The researcher does not change or influence the conditions, the individuals or elements of the situations in any way.

\subsection{Sample}

This research was conducted with 148 science teachers from 17 elementary schools in Ankara province Turkey. The sample was created by using the purposive sampling method, but the all participants were at various districts of urban area. As a non random sampling method it allows a detailed study of situations, which are considered to contain significant and rich information.

\subsection{The Instrument and Data Analysis}

Data was collected by a survey called "Questionnaire for Determining Teachers Opinions about Performance Assessment". It was created by the researchers in order to determine the views of the participant teachers about the performance assessment they use within the scope of their science courses. The survey included questions related to selected four-items for analysis. All items had multiple choices and teachers could choose more than one options for just one item. They were "the frequency of using performance tasks", "encounter problems about performance assessment application", "the aim of using performance assessment in classroom" and "evaluate procedures of performance tasks".

The gathered data from survey was analyzed via frequency and percentage analysis. Comparative graphics were created by using the distribution of these percentages.

\section{Results}

The first research item was determining the frequency of using performance assessment by teachers during the science classroom exercises. The teachers were asked how many times they used performance assessment in an educational year. The responses were presented in Figure 1.

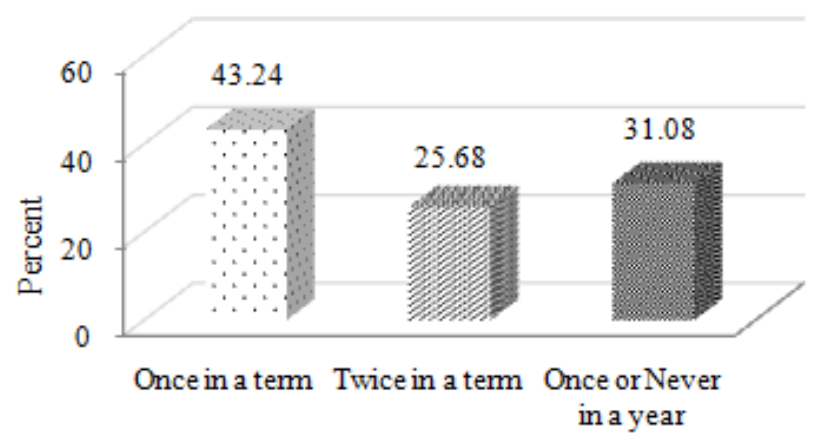

Figure 1. The frequency of using performance assessment in an educational year or in a term.

In Figure 1 presented that almost half of the teachers $(43.24 \%)$ preferred to use the performance assessment once in a term. The quarter of them (24.68) would have used it twice during the educational term. On the other hand the percentage of teachers who used it never or once in a year is $31.08 \%$ and the number of teacher who denied using it was remarkable.

The second research question was determining the reason of using performance assessment. This question will give us information about whether the teachers have adequate knowledge about the primary purpose of using it or not. That question included six options and distribution of them was shown below at the Figure 2 .

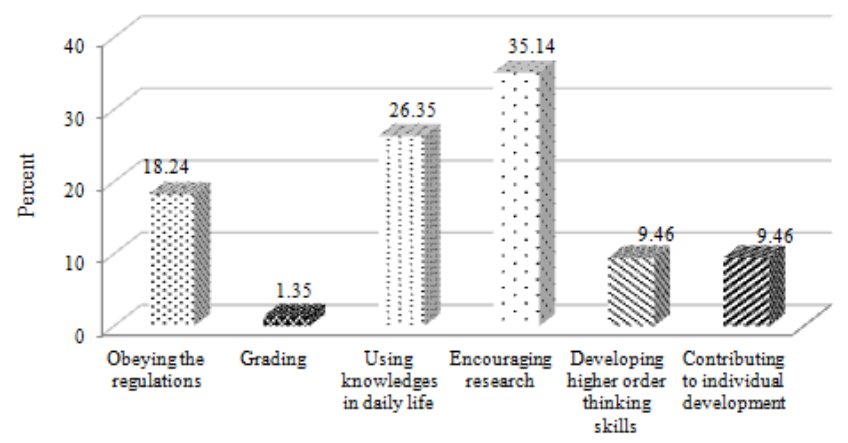

Figure 2. The reason of using performance assessment.

When Figure 2 was examined, most of the teachers' 
(35.14\%) primary purpose was "encouraging students to research". It means that they would have liked to improve student's research skills include problem solving and creativity. The second preferred reason (26.35\%) was "transferring learned science information to its applications in real life". They would have liked to observe that student should apply his knowledge on the daily life situations. On the other hand almost $20 \%$ of the teachers said that they used performance assessment during the science education just because of the curriculum. They had to obey the regulations of the curriculum and they didn't mind the primary purpose or didn't know about it. Some of them $(9.46 \%)$ applied these tasks because they wanted to develop student's high order thinking skills and contribute to student's individual development. For both categories the percentage is the same. Figure 2 also showed that a few teachers $(1.35 \%)$ stated that their primary purpose for using performance assessment was to only grade the student's work.

For the third question, we asked to the teachers which difficulties they encountered while they were using performance assessment. The results were shown in Figure 3.

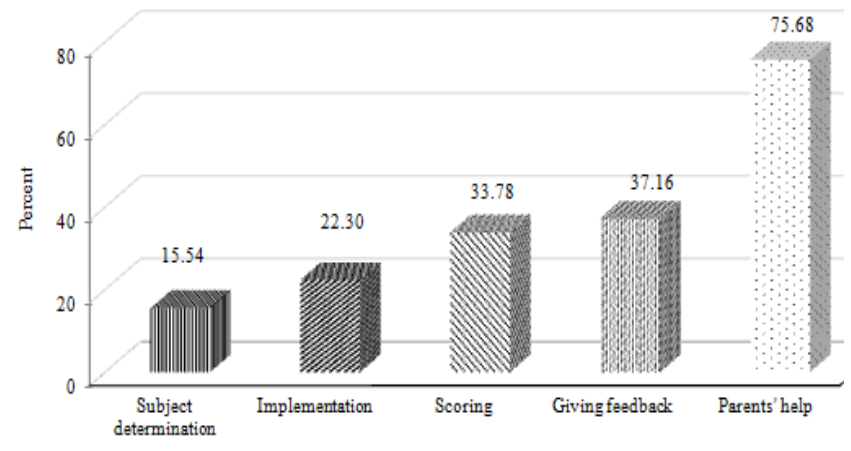

Figure 3. The difficulties of using performance assessment.

The three quarters of teachers $(75.68 \%)$ stated that parents' help is the most important problem while the students were completing performance assessment at home. It was required that students should have exhibited his performance by completing task but parents assisted their kids more than teachers expect. They were sometimes doing whole assignment on behalf of students and thus, they had difficulty in evaluating student's work. The second most encountered problem was evaluation process. The similar percentage of teachers had difficulties with giving feedback $(37.16 \%)$ and scoring them (33.76). $22.30 \%$ of them believed that they had difficulties during the implementation phase of the assessment. $15.54 \%$ of them stated that the most difficult part was to determine the subject concerned curriculum.

In performance assessment evaluation of student's work is an important issue. As mentioned previous finding, most of the teachers faced several difficulties about evaluating of the student's performance assessment product. Last research question was about evaluation. Teachers were asked which approaches they used during evaluating the performance assessment. Distribution was shown in Figure 4.

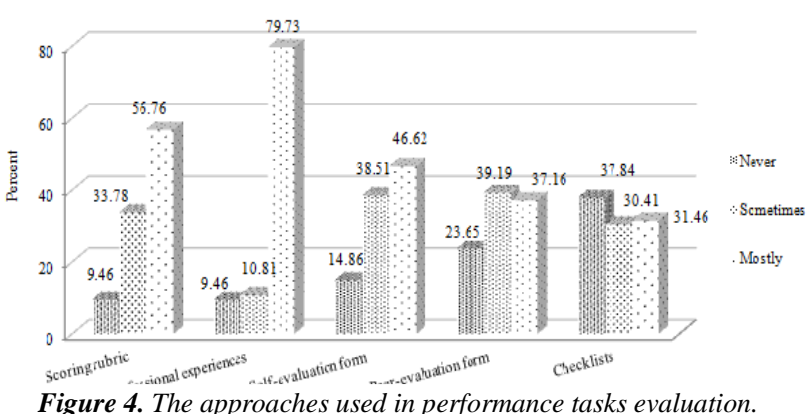

Figure 4. The approaches used in performance tasks evaluation.

When Figure 4 was examined, it seemed that many teachers preferred to use more than one tools instead of just one. Teachers mostly used their professional experiences $(79.73 \%)$ for grading student's product. Just half of them mostly used rubric (56.76) that was recommended tool by literature. In terms of objectivity of the evaluation, using personal opinions is risky. On the other hand almost half of them also preferred to use self assessment forms. Peer evaluation forms and check lists were the other approaches for evaluating. For both categories there wasn't a big difference among the percentage of the options, they were around $30.00 \%$. Some teachers were tending to use them frequently, some of them were refusing. However, the frequency of using these tools was less than the others.

\section{Discussion}

The research finding indicated that teachers used performance assessment with a low degree of frequency. Particularly, the percentage of teachers who prefer to use performance assessment only once or never in an educational year is striking. Among the most important reason for using performance assessment with a low frequency is that the proficiency of teachers in using these approaches is low. Roll's study (2003) supported this finding. More than half of teachers in Roll's study reported their knowledge with performance assessment as medium or low levels. This comes closer to some research findings. These studies indicated that teachers have not enough knowledge about the alternative assessment approaches, have difficulties in using these approaches when they need it, and therefore, they could not implement these approaches efficiently (Acad \& Demir, 2007; Sağlam, Avcı , \& İyibil, 2008). The limited time for the weekly course hours, large population of the classes, worries of teachers for not being able to complete the curriculum and inefficient use of time by the teachers were mentioned as the other reasons for using performance assessment with a low frequency (Acad \& Demir, 2007; Çoşkun, Gelen , \& Kan, 2009). In many studies, the lack of time issue was a common theme that was mentioned by the teachers. They indicated that it required a great deal of time to develop, implement and grade performance assessments (Aschbacher 1993; Craw, 2009; Roll, 2003). Despite that finding, some of the researches show that teachers used performance assessment with a high degree of frequency (Marzano, et al., 1993; Shepard, 2000; Stiggins, 2002).If teacher has adequate environment for 
applying performance assessment in the class, they would prefer to use it.

The question about the primary purposes of teachers to use performance assessment in their classroom was answered with different responses by teachers. A quarter of teachers stated that their primary purpose for using performance assessment was "transferring learned science in the classroom to its applications in real life" and one-third of them stated as "encouraging students to research and collect data". Benchmarks for Scientific Literacy (AAAS, 1993) and NSES (NRC, 1996) reveal that the learning of science starts to give way to the acquisition of inquiry skills, ability to collect and analyze data and ability to make connections between science content learned in the classroom and its applications in real life (Brickhouse, 2006; NRC, 1996). In performance assessment, a student can collect and analyze data to solve a problem or come across tasks with daily life situations, because the structure of performance tasks is suitable for using these types of examples. Our findings reveal that many teachers were aware of primary purposes of performance assessment in classroom. On the other hand, the percentage of teachers who stated that they were using performance assessment just for obeying the regulations in the curriculum was quite high. This indicated that teachers tended to obey the legal regulations of Ministry of Education (MEB) instead of benefiting from the advantages of performance assessment mentioned in literature. If a teacher doesn't take account of principal purpose of performance assessment, the teacher may make a mistake in selecting an accurate performances task or evaluation of a student's work. A performance assessment not well enough constructed can have a negative effect on student learning.

Performance assessment assesses not only content knowledge and inquiry skills, but also assesses students' higher order thinking skills. According to our findings, the low frequency of the teachers stated that the main purpose of using performance assessment was to assess improvement of the high order thinking skills of the student. In contrast to this finding, in Craw's research, he (2009) reported that many teachers used performance assessments in classroom because they thought that performance assessment promoted the application of knowledge and skills and encouraged higher order thinking. In our research the percentage of this category might be low as the teachers didn't have enough knowledge about the purpose of performance assessments. The studies showed that only few of the teachers had enough knowledge on the purposes of performance assessment (Metin, \& Özmen, 2010; Yapıc1 \& Demirdelen, 2007).

In this study a few teachers stated that their primary purpose for using performance assessment was to grade the students. Using performance assessment only to grade students' assignments couldn't be the primary purpose. Performance assessment includes facilities for teachers to grade students' work truly. At this point rubric has an important role in evaluation student's work. It makes it easier for teachers to observe the learning process and give feedback (Gallavan \& Kotler, 2009). When teachers are aware of the benefits of using performance assessment at grading of students' assignments, the primary purposes of their using performance tasks may be grading.

The most frequently stated problem by teachers in using performance assessment is that of parents' assistance while the students were completing performance assessment at home. Teachers mentioned that parents had a great role in students' completing performance tasks, and thus, they had difficulty in evaluating a student's product. Çoşkun, Gelen and Kan (2009) and Anıl and Acar (2009) reported similar problem in their research. In literature, it has been suggested that parents may help their children to a certain extent while developing some skills through performance assessment (Cooper, 1989; Miller \& Kelley, 1992). However, the problem in Turkey is that parents complete a student's work on behalf of the student rather than facilitating and contributing at a certain level.

Other frequent problems that the teachers encounter about performance assessment are "Scoring the performance assessment" and "Giving feedback to the students". Taking into consideration the common points in both issues, it can be argued that teachers have problems in evaluating of students' work. The assessment of students' products requires the use appropriate tools in performance assessment. In this context, the use of rubrics is a must. This finding may show that the teacher doesn't have knowledge about adequate tools while evaluating the performance assessment product of the students. Teachers should use valid and reliable tools in assessment. However, teachers are not always perfect in choosing assessment tools that would provide the most effective and the best results (Black \& William, 1998). If teachers do not use adequate educational equipments such as rubrics to evaluate the students' assignment, they will be evaluated inaccurately.

Other findings stated that teachers frequently used their professional experiences while making a decision about evaluating the student's work. In terms of objectivity of the evaluation, it is risky that a great number of teachers used their professional experience and their opinions about the students. This might be caused by the fact that teachers did not have enough knowledge about the tools to be used in evaluating performance tasks. This finding was parallel with the literature. The related literature discusses lack of pre-services and in-services training, lack of quality professional development training in assessment and lack of specific training in performance assessment (Kuran \& Kanatlı, 2009; Stiggins, 2002). The teachers who did not have any knowledge about performance assessment and evaluation might prefer to use their professional experience in evaluating student's work.

Only half of teachers stated that they use rubrics while evaluating the student's work. In other studies, the most of the teachers stated that their performance assessment practices included the use of rubrics most of time (Craw, 2009; Goodrich, 1997). The performance assessment requires the definitions and analysis of students' responses. Therefore, rubrics have become very important in the assessment of the students' achievements about the related performance (NCTM, 2000). Rubrics help to discover the learning outcomes related to conceptual and practical details and to evaluate both process and product 
together at different performance levels. In this context, rubrics have appeared to be the preferred tool in assessment. The fact that teachers do not have enough knowledge about the rubrics will cause the evaluation of the students' products inaccurately and it will turn the course into chaos (Meiera, Richa, \& Cadyb, 2006). It is somehow inevitable that teachers, who do not have enough knowledge about this tool, spend so much time to prepare, apply and score.

Teachers also preferred to use self evaluation of student, peer evaluation and checklists while evaluating performance assessment. However, the frequency of using these tools was lower than the others. It may be that some of the teachers in this study have not been given sufficient professional development in self-assessment techniques. Craw (2009) had a similar finding. He reported that there were few teachers who engaged students in self- or peer-assessment techniques. Those who did encouraged students to think about their learning and set goals for themselves. However, in literature, researchers consider the importance of self-regulation as an essential habit of mind (Costa \& Kallick, 2000; Marzano, et al, 1993). Teaching students how to identify strengths, weaknesses and set goals for themselves are some of the most important skills that students need to develop to become independent learners.

\section{Conclusion}

In science curriculum, alternative assessment methods have an important role in using and developing student's cognitive, affective and psychomotor skills. This study indicated that the frequency of teachers who used performance assessment in the classroom was very low. There were some findings about low-proficiencies of teachers about alternative assessment and training support for improving of their knowledge in new assessment techniques. The Ministry of Education in Turkey (MEB) or schools should provide training programs for teachers to develop their knowledge about alternative assessment, especially performance assessment.

The findings from this study showed that some of teachers were aware of main purposes of using performance assessment in classroom, but some of them weren't. A few teachers use performance assessment in classroom to develop a student's higher order thinking skills or contributing to a student's individual development. These findings highlight the fact that teachers should be informed about the advantages and the main purpose of performance assessment. More descriptive information about performance assessment can be part of teachers' training books.

In this study, the teachers mentioned that parents had a great role in a student's assignments while they complete performance assessment, and thus, they had difficulty in evaluating a student's work. This finding showed that parents need to have more information about the purpose of using performance assessment in the classroom. In this regard, the teachers may take this responsibility.

In the 21 st century, it is important for students to develop lifelong learning skills that enable them to evaluate their own work and set goals for themselves. Only a few teachers in this study indicated that they provided students with opportunities to periodically self-assess their work. The advantages of employing self-assessment should be discussed and modeled for teachers.

The teachers indicated that they have problems in evaluating of a student's work and there are still some teachers who stated that they do not use rubrics while evaluating students' work. The findings from this study highlight that the teachers need to improve proficiency in using rubrics when they need them and provide training in assessment of student's work. By way of organizing in-service training, the teachers' difficulties with using performance assessment should be removed. Teachers ought to be encouraged to use rubrics when they evaluate students' work. The quality of the information and examples of performance assessment in the resource books should be improved.

\section{References}

[1] Acat, B, \& Demir, E. (2007, September). Sinıf Öğretmenlerinin Ilköğretim Programlarındaki Değerlendirme Süreçlerine Ilişskin Görüşleri. Paper presented at 16. Ulusal Eğitim Bilimleri Kongresi, Gaziosmanpaşa Üniversitesi, Tokat.

[2] American Association for the Advancement of Science [AAAS] (1993). Benchmarks for Science Literacy. New York: Oxford University Press.

[3] Anıl, D., \& Acar, M. (2008). Sınıf Öğretmenlerinin Ölçme Değerlendirme Sürecinde Karşılaştıkları Sorunlara Ilişkin Görüşleri, Yüzüncü Yıl Üniversitesi Eğitim Fakültesi Dergisi, $5(2), 44-61$

[4] Aschbacher, P. R. (1993). Issues in Innovative Assessment for Classroom Practice: Barriers and Facilitators (CSE Tech. Rep. No. 359). Los Angeles: University of California, Center for Research on Evaluation, Standards and Student Testing (CRESST).

[5] Ayas, A., Çepni, S., \& Akdeniz, A.R. (1993). Development of the Turkish Secondary Science Curriculum. Science Education, 77, (4), 433-440.

[6] Berliner, D. C. (2006). Our Impoverished View of Educational Reform. Teachers College Record, 108(6), 949-995.

[7] Black, P., \& William, D. (1998). Assessment and Classroom Learning. Assessment in Education: Principles, Policy, and Practice, 5(1), 7-74.

[8] Brickhouse, N., W. (2006). Celebrating 90 Years of Science Education: Reflections on the Gold Standard and Ways of Promoting Good Research. Science Education, 90 (1).

[9] Cooper, H. (1989). Homework. New York: Longman

[10] Costa, A.L., \& Kallick, B. (2000). Discovering and Exploring Habits of Mind. Alexandria, VA: Association for Supervision and Curriculum Development.

[11] Coşkun, E., Gelen, İ., \& Kan, M. (2009). Türkçe Derslerindeki Performans Ödevleri Konusunda Öğretmen ve Öğrenci Görüşlerinin. Mustafa Kemal Üniversitesi Sosyal Bilimler Enstitüsü Dergisi, 6(11), 2255. 
[12] Craw, K. G. (2009). Performance Assessment Practices: A Case Study of Science Teachers in a Suburban High School Setting. Unpublished Doctoral Dissertation, Columbia University.

[13] Driver, R., Asoko, H., Leach, J. Mortimer, E. \& Scott, P. (1994). Constructing Scientific Knowledge in the Classroom. Educational Researcher. 23(7), 5-12.

[14] Elmore, P. B., \& Woehlke, P. L. (1988). Statistical Methods Employed in America Educational Research Journal, Educational Researcher and Review of Educational Research From 1978 to 1987. Educational Researcher, 17(9), 9-20.

[15] Gallavan, N. G. \& Kottler. E. (2009) Constructing Rubrics and Assessing Progress Collaboratively with Social Studies Students. Social Studies, 100(4), 154-159.

[16] Gallagher, J. (2006). Teaching Science for Understanding: a Practical Guide for Middle and High School Teachers. New Jersey: Prentice Hall.

[17] Gess-Newsome, J., Southerland, S. A., Johnston, A., \& Woodbury, S. (2003). Educational Reform, Personal Practical Theories, and Dissatisfaction: The Anatomy of Change in College Science Teaching. American Educational Research Journal, 40(3), 731-767.

[18] Goodrich, H. (1997). Understanding Rubrics. Educational Leadership, 54(4), 14-17.

[19] Haladyna, T. M. (1997). Writing Test Items to Evaluate Higher Order Thinking. USA: Allyn \&Bacon.

[20] Kaptan, F. (1998). Fen Bilgisi Öğretimi. İstanbul: MEB Yayınları Öğretmen Kitapları Dizisi.

[21] Sağlam-Arslan, A., Avcı, N., \& İyibil, Ü. (2008). Fizik Öğretmen Adaylarının Alternative Ölçme-Değerlendirme Yöntemlerini Algılama Düzeyleri. Dicle Üniversitesi Ziya Gökalp Eğitim Fakültesi Dergisi, 11, 115-128.

[22] Kuran, K. \& Kanatlı, F. (2009). Alternatif Ölçme Değerlendirme Teknikleri Konusunda Sınıf Öğretmenlerinin Görüşlerinin Değerlendirilmesi. Mustafa Kemal Üniversitesi Sosyal Bilimler Enstitüsü Dergisi, 6(12), 209-234.

[23] Kutlu, Ö., Doğan, C. D., \& Karakaya, İ. (2008). Öğrenci Başarısının Belirlenmesi. Ankara: Pegem Akademi Yayıncılık

[24] Martin, R., Sexton, C., \& Gerlovich, J. (2001) Teaching Science for All Children. Boston: Allyn and Bacon.

[25] Marzano, R. J., Pickering, D., \& McTighe, J. (1993). Assessing Student Outcomes, Alexandria:Association for Supervision and Curriculum Development, 1(5), 37-43.

[26] MEB, Talim ve Terbiye Genel Kurulu Başkanlığı. (2005). İlköğretim Fen ve Teknoloji Dersi (4.-5.Sinıflar) Öğretim Programi. Retrieved from http://ttkb.meb.gov.tr/ogretmen/modules.php?name=download s\&d_op=viewdownload\&cid=74 Accessed January 6, 2012.

[27] Meiera., S. L., Richa, B. S., \& Cadyb J. (2006). Teachers' Use of Rubrics to Score Nontraditional Tasks: Factors Related to
Discrepancies in Scoring. Assessment in Education, 13(1), 69-95.

[28] Mehrens, W. A. (1992). Using Performance Assessment for Accountability Purposes. Educational Measurement, 11(4), 3-9.

[29] Metin, M., \& Özmen, H. (2010). Fen ve Teknoloji Öğretmenlerinin Performans Değerlendirmeye Yönelik Hizmet İçi Eğitim (HİE) Ihtiyaçlarının Belirlenmesi. Kastamonu Ĕgitim Dergisi, 18(3), 819-838.

[30] Miller, D. L., \& Kelley, M. L. (1992). Interventions for Improving Homework Performance: a Critical Review. School Psychology Quarterly, 6, 174-185.

[31] National Research Council. (1996). National Science Education Standards. Washington, DC: National Academy Press.

[32] National Council of Teachers of Mathematics (NCTM). (2000). Principles and Standards for School Mathematics. Reston, VA: author.

[33] Popham, W. J. (2005). Modern Education Measurement. USA: Allyn and Bacon.

[34] Reynolds, C. R., Livingston, R. B., \& Wilson, W. (2006). Measurement and Assessment in Education. Boston, MA: Pearson/Allyn and Bacon

[35] Roll, (2003). Performance Assessments: Middle School Teacher Knowledge and Practice. Unpublished Doctoral Dissertation, Johnson and Wales University, Rhode Island.

[36] Ryan, T.G. (2006). Performance Assessment: Critics, Criticism, and Controversy. International Journal of Testing, 6(1), 97-104.

[37] Sağlam Arslan, A., Avc1, N. \& İyibil, Ü. (2008). Fizik Öğretmen Adaylarının Alternative Ölçme Değerlendirme Yöntemlerini Algılama Düzeyleri. Dicle Üniversitesi Ziya Gökalp Eğitim Fakültesi Dergisi, 11, 115-128.

[38] Shepard, L. A. 2000. The Role of Assessment in a Learning Culture. Educational Researcher, 29(7), 4-14.

[39] Stiggins, R.J. (2002). Assessment crisis: The absence of assessment for learning. Phi Delta Kappan, 83(10), 758-765.

[40] Wehlange, G. G., Newmann, F. M.,\& Secada, W. G. (1996). Standarts of Authentic Achievement and Pedagogy. In F. M. Newmann (Eds.), Restructuring schools for intellectual quality (pp.21-48). San Francisco, CA:Jossey Bass.

[41] Wiggins, G. (1989). Teaching to the (Authentic) Test. Educational Leadership, 46 (7), 41-47.

[42] Yager, R. E., \& Penick, J. E. (1988). Changes in Perceived Attitudes toward the Goals for Science Instruction in Schools. Journal of Research in Science Teaching, 25 (3), 17984.

[43] Yapıcı, M. \& Demirdelen, C. (2007). İlköğretim 4. Sınıf Sosyal Bilgiler Programına İlişkin Öğretmen Görüşleri. İlkögrretim-Online, 6(2), 204-212. 